\title{
Accumulation of steroid hormones in soil and its adjacent aquatic environment from a typical intensive vegetable cultivation of North China
}

\author{
Feng-Song Zhang ${ }^{a}$, Yun-Feng Xie ${ }^{\mathrm{b}, *}$, Xue-Wen Li $^{\mathrm{c}}$, Dai-Yi Wang ${ }^{\mathrm{b}}$, Lin-Sheng Yang ${ }^{\mathrm{a}, *}$, Zhi-Qiang Nie ${ }^{\mathrm{b}}$ \\ a Key Laboratory of Land Surface Pattern and Simulation, Institute of Geographic Sciences and Natural Resources Research, Chinese Academy of Sciences, Beijing 100101, China \\ b State Key Laboratory of Environmental Criteria and Risk Assessment, Chinese Research Academy of Environmental Sciences, Beijing 100012, China \\ c Department of Environmental and Health, School of Public Health, Shandong University, Jinan, 250012, China
}

\section{H I G H L I G H T S}

- Seven steroids were detected in soil and adjacent drainage ditch sediment.

- Six steroids were found in drainage ditch water and groundwater.

- Progesterone, androstendione and estrone accumulated relatively easily in soils.

- Testosterone and estriol were easily leached to groundwater.

- Concentrations of steroids in soil and groundwater were highly spatially variable.

\section{G R A P H I C A L A B S T R A C T}

Accumulation of steroid hormones in (a) greenhouse soil, (b) ditch sediment, (c) ditch water and (d) groundwater.
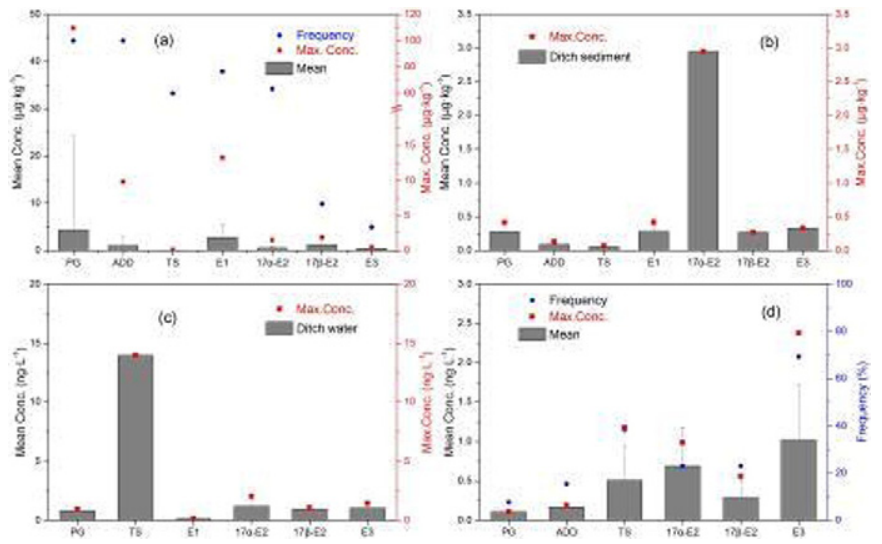

\section{A B S T R A C T}

Steroid hormones released from manure agricultural application are a matter of global concern. The residual levels of steroid hormones were studied in a typical intensive vegetable cultivation area in northeast China, with a long history of heavy manure application. Seven steroids (estrone, $17 \alpha$-estradiol, $17 \beta$-estradiol, estriol, testosterone, androstendione and progesterone) were analyzed from soil sampled from vegetable greenhouses, from sediments and water from the adjacent drainage ditch and from the groundwater. The results showed that target steroids were detected in the soil samples, with detection frequencies varying from 3.13 to $100 \%$. The steroid concentrations varied substantially in soils, ranging from below the detection limit to $109.7 \mu \mathrm{g} \cdot \mathrm{kg}^{-1}$. Three steroids-progesterone, androstendione and estrone-were found to have relatively high residue concentrations in soil, with maximum concentrations of $109.7,9.83$ and $13.30 \mu \mathrm{g} \cdot \mathrm{kg}^{-1}$, respectively. In adjacent groundwater, all the steroids, with the exception of estrone, were detected in one or more of the 13 groundwater samples. The concentrations of steroids in groundwater ranged from below the method detection limit to $2.38 \mathrm{ng} \cdot \mathrm{L}^{-1}$. Six of the seven (excluding androstendione) were detected in drainage ditch water samples, with concentrations ranging from below the detection limit to $14 \mathrm{ng} \cdot \mathrm{L}^{-1}$. Progesterone, androstendione and estrone accumulated relatively easily in soils; their concentrations in groundwater were lower than those of other steroids. The concentrations of testosterone and estriol were relatively low in soil, while in groundwater were higher than those of other steroids. The residual levels of steroids in soil and groundwater showed a clear spatial variation in the

\footnotetext{
* Corresponding authors.

E-mail addresses: yunfxie@gmail.com (Y.-F. Xie), yangls@igsnrr.ac.cn (D.-Y. Wang).
} 
study area. The residual levels of steroid hormones in soil varied substantially between differently planted greenhouses.

\section{Introduction}

Natural steroid hormones have received considerable attention because of their endocrine-disrupting effects on aquatic organisms (Orlando et al., 2004; Alvarez et al., 2013). Environmentally-relevant concentrations of estrogen hormones in aquatic environments have been found sufficient to stimulate production of a female protein in male fish, with no effect concentrations for $17 \beta$-estradiol of $1-10 \mathrm{ng} \cdot \mathrm{L}^{-1}$ (Routledge et al., 1998). Livestock manure is accepted as an important source of these compounds with major inputs to the environment (Shore and Shemesh, 2003; Lorenzen et al., 2004; Bevacqua et al., 2011). Natural estrogens were detected in various types of animal wastes, such as $17 \beta$-estradiol content of between 14 and $904 \mathrm{mg} \cdot \mathrm{kg}^{-1}$ in poultry litter (Gall et al., 2011; Hanselman et al., 2003). Luo et al. (2013) reported that estrogen content, including estrone, $17 \alpha$-estradiol, $17 \beta$-estradiol and estriol in water and sediments, increased within a watershed that was subject to animal manure application. Animal manures contain more androgens and gestagens than estrogen hormones (Shore and Shemesh, 2003). It has been suggested that testosterone can suppress the antibody-forming cell responses in Chinook salmon (Slater and Schreck, 1993). Shore et al. (2004) showed that testosterone accumulated in a watershed originated from washout of cattle pasture. Progesterone is also frequently detected in waste storage lagoons and shed effluents and could be potentially hazardous to the environment (Gadd et al., 2010; Liu et al., 2012).

Manure-borne hormones can be transported to surface water through runoff produced by rainfall or irrigation. Mimic rainfall experiments have confirmed that animal manure application increases concentrations of steroid hormones in runoff (Kolodziej and Sedlak, 2007; Jenkins et al., 2009; Gall et al., 2011; DeLaune and Moore, 2013). For example, high (up to $58 \mathrm{ng} \mathrm{L}^{-1}$ ) estrone concentrations were measured shortly after applications of manure in a small agricultural watershed (Lafrance and Caron, 2013). Manure type, application rate, and time until the first runoff event occurs after manure application will affect the transport of steroid hormones to surface water (DeLaune and Moore, 2013). Such research was only concerned with the risk of manure steroids entering surface water from animal manure applications directly (Gadd et al., 2010; Liu et al., 2012; Yost, et al., 2014; Bartelt-Hunt et al., 2012; Gall et al., 2011). Residues of steroids in animal manure can also leach through soil into the groundwater. Groundwater underlying livestock wastewater impoundments has also been shown to contain natural steroid hormones (Arnon et al., 2008; Bartelt-Hunt et al., 2011). To our knowledge, there has been little investigation into the occurrence of steroid hormones in groundwater associated with animal manure agricultural application.

Long-term animal manure application will increase pollutant accumulation in agricultural soils, including heavy metals and antibiotic compounds (Li et al., 2015a,b). Recent research indicated that estrogen in pig slurry redistributed in soils and remained present in the soil for 46 days (Mostofa Amin et al., 2014). Experiments confirmed that steroid hormones entering agricultural soil could be assimilated by lettuce and maize and might represent a human health risk (Card et al., 2013; Shargil et al., 2015). China's economic boom in recent decades has stimulated demand for non-seasonal vegetable products that has consequently led to a vast expansion of vegetable production. To improve vegetable production, much more animal manure has been applied to vegetable greenhouses than to grain cropland (Li et al., 2014). However, most of the livestock and poultry feces contain antibiotic residues and estrogens and are applied to soil without effective treatment ( $\mathrm{Hu}$ et al., 2010; Zhang et al., 2014). Our previous study showed that the soil might be contaminated by antibiotic residues from chicken manure in Shouguang, which has the largest vegetable cultivation base in north China (Li et al., 2014).

The objectives of this study were to investigate the occurrence and concentration of steroids in soils, drainage ditch water, sediments and groundwater in the vegetable production base in Shouguang; to explore the spatial pattern of steroids in soils and groundwater; and to analyze the differences in steroid distribution between soil, water and sediment.

\section{Materials and methods}

\subsection{Study area}

The study area was a typical intensive vegetable cultivation region in Shouguang, Shandong Province, northeast China. The study region covers an area of about $160 \mathrm{~km}^{2}$. The region has a warm, temperate, continental monsoon climate with seasonal changes (e.g., hot and rainy in summer; cold and dry in winter). The annual average temperature is $12.7^{\circ} \mathrm{C}$ and the hottest and coldest months are June and January, with monthly average temperatures of $26.5^{\circ} \mathrm{C}$ and $-3.1{ }^{\circ} \mathrm{C}$, respectively. The annual precipitation is about $593.8 \mathrm{~mm}$, and rainfall is most frequent in June, July, and August.

Shouguang, located in Shandong Province, is the major vegetable production base in northern China, with several hundred years of cultivation history and 25 years of vegetable cultivation using greenhouses. The vegetables are grown in large greenhouses between 500 and $1000 \mathrm{~m}^{2}$ in area. The primary vegetables grown in the region are cucumbers, tomatoes, peppers, melons, and eggplant. Vegetables are cultivated in 2-3 crop cycles per year, and are fertilized in autumn or winter, 1-2 times per year. Animal manure, such as chicken manure and cow dung, has been used as organic fertilizer for several years, and is mainly sourced from the local livestock and poultry farms of the surrounding counties. The annual manure application quantity ranged from 1.3 to $17.1 \mathrm{~kg} \cdot \mathrm{m}^{-2}$.

\subsection{Sampling}

Sampling was performed in October, 2013. The soils and adjacent ditch water, sediments, and underground water were sampled for analysis of seven types of target steroid hormones, including estrone (E1), $17 \alpha$-estradiol (17 $\alpha$-E2), $17 \beta$-estradiol (17 $\beta$-E2), estriol (E3), androstendione (ADD), testosterone (TS) and progesterone (PG). A total of 32 surface soil samples, including 30 greenhouse soils and two non-greenhouse soils, were collected. The greenhouse soils were sampled from seven types of greenhouse plots; cucumber, pepper, eggplant, luffa, melon, tomato and coriander (Fig. 1). Each surface soil sample was collected from one vegetable greenhouse. Using a small shovel, soil samples were collected from $0-15 \mathrm{~cm}$ below the soil surface. Five sampling sites were distributed along an S-shaped path within each greenhouse, then fully mixed to form a single composite sample. 3 Surface water samples and 3 sediment samples were taken from the drainage ditches adjacent to the greenhouses. Surface water samples were collected at $0-1 \mathrm{~m}$ overlying water depths. Sodium azide was added to the water samples at $200 \mathrm{mg} \cdot \mathrm{L}^{-1}$. The surface sediment samples (5-cm depth) were collected using a grab sampler. A total of 13 groundwater samples were collected from irrigation wells that were usually within $100 \mathrm{~m}$ of the greenhouses. All samples were transported to the laboratory within $7 \mathrm{~h}$ of collection; the water samples were immediately analyzed once transported to the laboratory and soil and sediment samples were stored at $-20{ }^{\circ} \mathrm{C}$ for further extraction and analysis. 

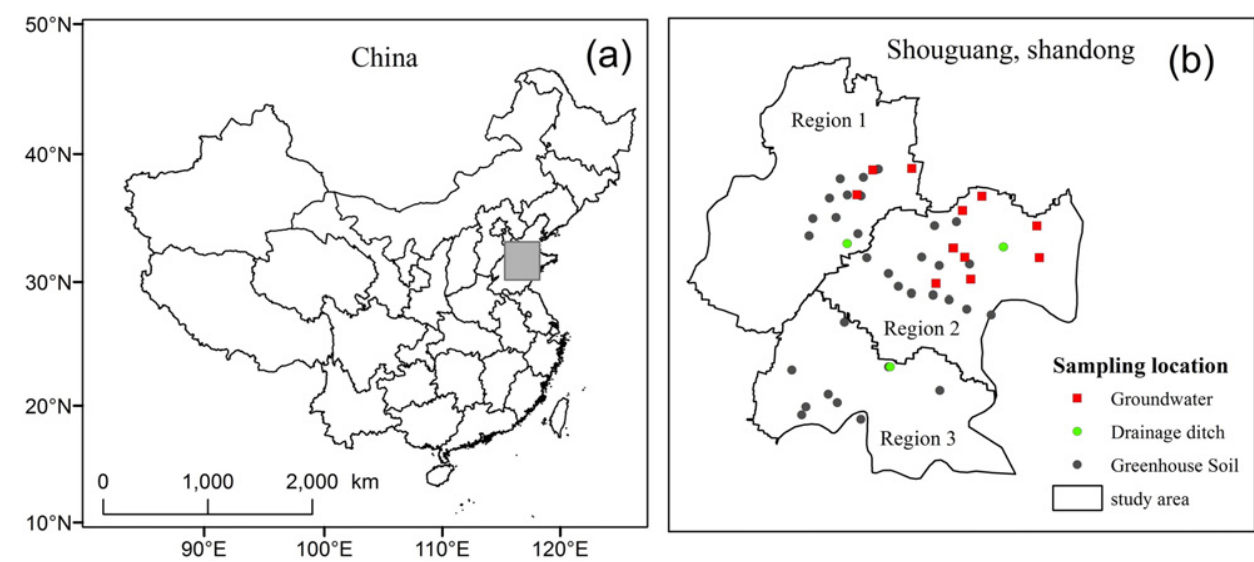

Fig. 1. Location of the study area in China (a) and the sampling distribution of soil, groundwater, and the drainage ditch water and sediments sampled (b).

\subsection{Sample extraction and cleanup}

Each water sample (1500 mL) was filtered through glass fiber filters (GF/F, 0.7- $\mu \mathrm{m}$ pore size; Whatman). After filtration of the sample, the extraction and clean-up procedure included three steps, which were modified from the methods described in previous studies (Hu et al., 2005; Chang et al., 2009; Tso et al., 2011). First, solutions were extracted onto a conditioned $(6 \mathrm{~mL}$ ethyl acetate methanol, $6 \mathrm{~mL}$ acetonitrile, $12 \mathrm{~mL}$ water) HLB Oasis Plus cartridge (500 mg, $6 \mathrm{~cm}^{3}$, Waters, Mississauga, ON, Canada) at a flow rate of about $10 \mathrm{~mL} \cdot \mathrm{min}^{-1}$. The cartridge was then washed with $10 \mathrm{~mL} \mathrm{ul-}$ trapure water and $5 \mathrm{~mL} \mathrm{50 \%} \mathrm{methanol} \mathrm{in} \mathrm{water}\left(20 \mathrm{~m} \cdot \mathrm{min}^{-1}\right)$, and dried by suction for $30 \mathrm{~min}$. Elution was then performed with $15 \mathrm{~mL}$ ethyl acetate and $6 \mathrm{~mL}$ ethyl acetate and acetonitrile $(1: 1$, $\mathrm{v}: \mathrm{v})$. The extracts were then evaporated to dryness under a gentle nitrogen flow, and subsequently dissolved in $2 \mathrm{~mL}$ methanol and ethyl acetate $(4: 6, v: v)$. Second, the reconstituted sample of the previous step was extracted through an $\mathrm{NH}_{2}$ cartridge $\left(500 \mathrm{mg}, 3 \mathrm{~cm}^{3}\right.$, Waters, Mississauga, ON, Canada) conditioned with $4 \mathrm{~mL}$ methanol and ethyl acetate (4:6, v:v) and $4 \mathrm{~mL}$ water-saturated ethyl acetate. The $\mathrm{NH}_{2}$ cartridge was then washed into the same test tube with $2 \mathrm{~mL}$ methanol and ethyl acetate $\left(4: 6, \mathrm{v}: \mathrm{v}, 2 \mathrm{~mL} \cdot \mathrm{min}^{-1}\right)$. The wash was performed twice with $1 \mathrm{~mL}$ of washing solution each time and sonicated for $1 \mathrm{~min}$. Finally, the reconstituted solution and washing solution were collected into one $10-\mathrm{mL}$ test tube and dried under a gentle stream of nitrogen, and subsequently dissolved in $0.2 \mathrm{~mL}$ of ethyl acetate and vortexed, then sonicated for $1 \mathrm{~min}$. Subsequently, $1-\mathrm{mL} \mathrm{n}$-hexane was added and vortexed until well mixed. Finally, the mixture was extracted through a Silica cartridge $(500 \mathrm{mg}$, $3 \mathrm{~cm}^{3}$ ) that was successively rinsed $\left(20 \mathrm{~mL} \cdot \mathrm{min}^{-1}\right)$ with $4 \mathrm{~mL}$ water-saturated ethyl acetate, $4 \mathrm{~mL}$-hexane and ethyl acetate (9:1, v:v). These cartridges were subsequently washed with $3 \mathrm{~mL}$ n-hexane and ethyl acetate (9:1, v:v), followed by elution with $6 \mathrm{~mL}$ water-saturated ethyl acetate. The elution was then evaporated to dryness under a nitrogen stream, and redissolved in $0.5 \mathrm{~mL} \mathrm{50 \%}$ methanol, and sonicated for $1 \mathrm{~min}$. Finally, the samples were kept in labeled screw vials at $-20{ }^{\circ} \mathrm{C}$ until analysis.

Each part of the soil and sediment samples (about $50 \mathrm{~g}$ ) was placed in a freeze-dryer to remove all the water, then ground to pass through a 2.0 -mm-mesh nylon sieve prior to analysis. Lyophilized soil $(2.0 \mathrm{~g})$ was extracted in $20 \mathrm{~mL}$ of ethyl acetate and sonicated for $20 \mathrm{~min}$, and then centrifuged at $5000 \mathrm{rpm}$ in air-cooled conditions. The extraction procedure with ethyl acetate was performed twice, and finally, the supernatants were combined (approximately $40 \mathrm{~mL}$ ). The supernatants were then evaporated to near dryness using a rotary evaporator, then diluted with $200 \mathrm{~mL}$ water to maintain the content of organic solvent under $10 \%$, where they were then processed through the three clean-up steps as described above for water samples.

\subsection{Instrumental analytical methods}

The concentrations of steroids in water and soil were analyzed using an Acquity UPLC-ESI/MS/MS (Waters Corporation, Milford, MA, USA), equipped with an Acquity UPLC-TM BECH $\mathrm{C}_{18}$ column $(2.1 \times 50 \mathrm{~mm}$, $1.7 \mu \mathrm{m})$. Instrument control, data acquisition and evaluation used Mass Lynx 4.1 software (Waters Corporation). The mobile phase consisted of water (A) and acetonitrile (B) with 0 to 2 min at $5-35 \%$ B, 2 to $4 \mathrm{~min}$ at $35-45 \% \mathrm{~B}, 8$ to $8.5 \mathrm{~min}$ at $45-95 \% \mathrm{~B}, 8.5$ to $10 \mathrm{~min}$ at $95 \%$ $\mathrm{B}, 10$ to $10.5 \mathrm{~min}$ at $95-5 \% \mathrm{~B}$, and 10.5 to $12 \mathrm{~min}$ at $5 \% \mathrm{~B}$. The mobile phase gradient was ramped at a flow rate of $0.3 \mathrm{~mL} \cdot \mathrm{min}^{-1}$ and $10 \mu \mathrm{L}$ of the extract was injected into the chromatographic system. The quantitative analysis of the target steroid was carried out in multiple reactions monitoring mode with argon collision gas. Source temperature was set as $110^{\circ} \mathrm{C}$ and the desolvation temperature as $350^{\circ} \mathrm{C}$. Nitrogen was used as both the nebulizing and the desolvation gas. The flowrate of the nebulizing gas was set at $50 \mathrm{~L} \cdot \mathrm{h}^{-1}$, and that of the desolvation gas at $800 \mathrm{~L} \cdot \mathrm{h}^{-1}$. The mass spectrometry was performed in both negative and positive ionization modes. The positive ionization mode was operated for the detection of androgens and progestagens; extractor voltage was $3 \mathrm{~V}$, and RF lens was $3.3 \mathrm{~V}$. The positive negative ionization mode was operated for the detection of estrogens; extractor voltage was $3 \mathrm{~V}$ and RF lens was $2.5 \mathrm{~V}$. Detection limits of these compounds are shown in Appendix Table A1.

\subsection{Quality assurance and quality control}

Recoveries of target steroids were determined by spiking the water samples, soil and sediment samples with standard solutions at concentrations of $20 \mu \mathrm{g} \cdot \mathrm{L}^{-1}, 20 \mu \mathrm{g} \cdot \mathrm{kg}^{-1}$ and $20 \mu \mathrm{g} \cdot \mathrm{kg}^{-1}$, respectively. Internal standards (D2-17 $\beta-E 2$ and D3-TS) were added to each sample before extraction to correct for extraction recoveries and matrix effects and variation of instrumental response. Recoveries (\%) and method detection limits (MDLs) in ditch water, soil and sediment were shown in Appendix Table A2. The recoveries of the seven steroids in water, soil and sediment samples ranged from $79.28 \%$ to $94.44 \%$ and from $73.67 \%$ to $95.50 \%$ and from $74.03 \%$ to $95.46 \%$, respectively; The method detection limits (MDLs) ranged from 0.03 to $0.24 \mu \mathrm{g} \cdot \mathrm{L}^{-1}$ for water samples and from 0.02 to $0.24 \mu \mathrm{g} \cdot \mathrm{kg}^{-1}$ for sediment samples and from 0.02 to $0.28 \mu \mathrm{g} \cdot \mathrm{kg}^{-1}$.

\section{Results and discussion}

3.1. Detection and distribution of steroids in soil, drainage ditch and groundwater

The seven target steroids were detected in soil samples from all the different greenhouses ( $n=30$ ), with the detection frequency ranging 
from 3.13 (E3) to 100\% (PG and ADD; Fig. 2). The concentration of steroids varied considerably in soils, with values that ranged from below the detection limit to $109.7 \mu \mathrm{g} \cdot \mathrm{kg}^{-1}$. PG, ADD and E1 were found to have relatively high residue concentrations in soil, with maximum concentrations of $109.7,9.83$ and $13.30 \mu \mathrm{g} \cdot \mathrm{kg}^{-1}$, respectively. The maximum concentrations of the other four steroids were below $2 \mu \mathrm{g} \cdot \mathrm{kg}^{-1}$. PG showed the highest average concentration of $4.15 \mu \mathrm{g} \cdot \mathrm{kg}^{-1}$. The average concentrations of E1 and $17 \beta-\mathrm{E} 2$ in greenhouse soil were 2.74 and $1.20 \mu \mathrm{g} \cdot \mathrm{kg}^{-1}$, respectively, with corresponding concentrations of $17 \alpha-$ $\mathrm{E} 2$ and $\mathrm{E} 3$ below $0.51 \mu \mathrm{g} \cdot \mathrm{kg}^{-1}$. For androgens, the average concentration of ADD was $1.05 \mu \mathrm{g} \cdot \mathrm{kg}^{-1}$, which was higher than that of TS $\left(0.07 \mu \mathrm{g} \cdot \mathrm{kg}^{-1}\right)$. Previous studies have shown the presence of estrogen residues in agricultural soils because applied animal manure contained a variety of steroids (Finlay-Moore et al., 2000; Jenkins et al., 2009; Mostofa Amin et al., 2014). However, different steroids are associated with different livestock species (Shore and Shemesh, 2003). In the greenhouses of this study area, there was a long history of the use of chicken manure as organic fertilizer. Poultry excreted 17 $\beta-E 2$, E1, and E3, while $17 \alpha-E 2$ rarely occurred in the excreta of poultry (Hanselman et al., 2003). This might explain the low content of $17 \alpha-$ E2 in greenhouse soil in this study. Mimic experiments indicated that estrogens such as $17 \beta-E 2$ degraded within a few days in various soils (Colucci et al., 2001; Lee et al., 2003; Xuan et al., 2008). Despite this, $17 \beta-E 2$ was frequently detected in surface soil applied animal manure (Jenkins et al., 2009; Mostofa Amin et al., 2014). According to Jenkins et al. (2009), a mean concentration of $17 \beta-E 2$ of $0.24 \mu \mathrm{g} \cdot \mathrm{kg}^{-1}$ was detected in surface-soil-applied broiler litters, which was much lower than the value obtained in this study $\left(1.20 \mu \mathrm{g} \cdot \mathrm{kg}^{-1}\right)$. This might indicate that long term application of broiler litters in greenhouse soils resulted in accumulation of $17 \beta-E 2$ in soils. Furthermore, $17 \beta-E 2$ can be rapidly converted into E1 (Colucci et al., 2001). This might explain why there was more E1 accumulated in greenhouse soils than $17 \beta-E 2$. In addition to estrogens, androgen residues in soil-applied chicken manure were previously reported (Finlay-Moore et al., 2000; Jenkins et al., 2009). For example, the average concentration of TS in surface-soil- applied broiler litters was $0.067 \mu \mathrm{g} \cdot \mathrm{kg}^{-1}$, which was similar to values obtained in this study. ADD is another important androgen that was frequently detected in animal manure (Liu et al., 2012; Mostofa Amin et al., 2014). Furthermore, it was one of the primary transformation products of TS in soil (Lorenzen et al., 2004). This might explain the higher average concentration of ADD in greenhouse soils compared with TS. PG is frequently detected in wastewaters and concentrated animal feeding operations (CAFOs) lagoons (Chang et al., 2009; Liu et al., 2012), and it was also liable to accumulate in soils with manure application (Mostofa Amin et al., 2014).

The residue levels of hormones in soil varied substantially between differently planted greenhouses (Table 1 ). The highest average concentrations of PG $\left(9.11 \mu \mathrm{g} \cdot \mathrm{kg}^{-1}\right)$ and ADD $\left(>1.30 \mu \mathrm{g} \cdot \mathrm{kg}^{-1}\right)$ in soil were both detected in the cucumber greenhouse. For E1, the highest average concentration of $7.93 \mu \mathrm{g} \cdot \mathrm{kg}^{-1}$ was found in the coriander greenhouse. There were no significant differences in TS and $17 \alpha$-E2 concentrations from different greenhouse soils, with average concentrations of less than $0.7 \mu \mathrm{g} \cdot \mathrm{kg}^{-1}$. In summary, the total content of PG, ADD, E1, TS and $17 \alpha-\mathrm{E} 2$ in different types of greenhouses was higher than that in non-greenhouse soil. In particular, cucumber and coriander greenhouse soil had the highest content of more than five hormones, with mean concentrations of 14.19 and $10.6 \mu \mathrm{g} \cdot \mathrm{kg}^{-1}$, respectively. There are several factors which may significantly affect the levels of steroids in different plant greenhouse soils. Steroids in greenhouse soils mainly came from the chicken manure including broiler litter and hens manure. Manure type and application rate will affect the residue of steroids in soils. The vegetable types were not uniform among the greenhouses and the nutrient requirements varied between different vegetables, therefore, the quantity of manure applied varied between greenhouses. The more frequency and amount of usage of chicken manure would result in more residue steroids in cucumber greenhouse soils. Furthermore, the contents of steroids were different among the two types of chicken manure. For example, E1 is often found in hens manure while rarely found in broiler litter. The fate and transport of steroids in soil were affected by the environment condition of greenhouse, such as
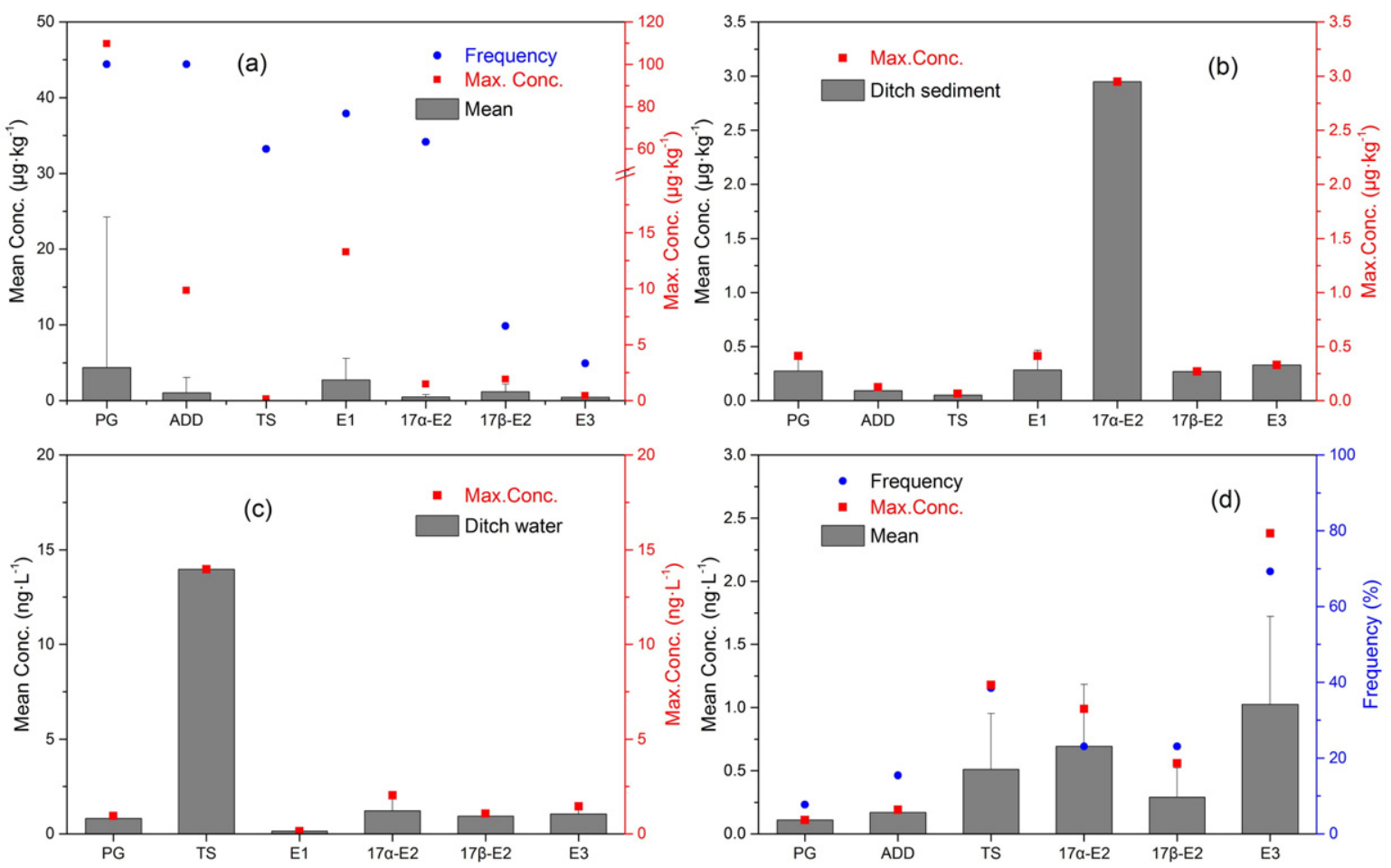

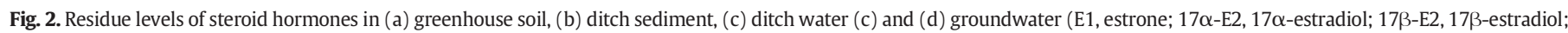
E3, estriol; ADD, androstendione; TS, testosterone; PG, progesterone). 
Table 1

Average concentrations of steroids in greenhouse and non-greenhouse soil $\left(\mu \mathrm{g} \cdot \mathrm{kg}^{-1}\right)$.

\begin{tabular}{llllllr}
\hline Plant type & PG & ADD & TS & E1 & $17 \alpha$-E2 & SUM \\
\hline Cucumber & 9.11 & 1.42 & 0.05 & 3.01 & 0.60 & 14.19 \\
Pepper & 0.66 & 0.25 & 0.05 & 2.37 & 0.36 & 3.69 \\
Eggplant & 0.89 & 0.33 & 0.05 & 2.93 & 0.28 & 4.48 \\
Luffa & 1.29 & 0.69 & $*$ & 0.52 & 0.36 & 2.86 \\
Melon & 0.84 & 0.90 & 0.05 & 1.90 & 0.64 & 4.32 \\
Tomato & 0.42 & 0.26 & 0.15 & 1.42 & 0.31 & 2.56 \\
Coriander & 0.63 & 1.38 & $*$ & 7.93 & 0.66 & 10.60 \\
Non-greenhouse soil & 0.86 & 0.07 & 0.06 & $*$ & 1.20 & 2.20 \\
\hline
\end{tabular}

SUM: the total of PG, ADD, TS, E1 and $17 \alpha-E 2$.

* The concentration was below the detection limit.

temperature, light and irrigation. However, these factors also varied among different vegetables. Meanwhile, the capacities to accumulate steroids from soil may be different among different types of vegetables, which will result in the differences in steroids residual concentration in soils.

All seven target steroids were found in sediments from ditches ( $n=$ 3 ) adjacent to greenhouses. The average concentrations of steroids in sediments ranged from 0.05 to $2.94 \mu \mathrm{g} \cdot \mathrm{kg}^{-1}$, with the highest concentration $\left(2.94 \mu \mathrm{g} \cdot \mathrm{kg}^{-1}\right)$ obtained for $17 \alpha$-E2. Except for $17 \alpha$-E2, the average concentrations of steroids in sediments were lower than the corresponding values in greenhouse soils. For ditch water, six steroids were detected in drainage ditch water samples $(n=3)$, with the exception of ADD (Fig. 2). Estrogens (E1, 17 $\alpha$-E2, 17 $\beta$-E2 and E3) had lower average concentrations $\left(3.35 \mathrm{ng} \cdot \mathrm{L}^{-1}\right)$ than TS $\left(14.0 \mathrm{ng} \cdot \mathrm{L}^{-1}\right)$ in ditch water, but were higher than PG $\left(0.82 \mathrm{ng} \cdot \mathrm{L}^{-1}\right) .17 \beta$-E2 had the highest estrogenic activity, which was 5-1000 times that of E1 and E3 (Lee et al., 2003; Legler et al., 2002). The maximum concentrations of $17 \beta-E 2,17 \alpha-$ E2 and E3 in ditch water were in the range of $1-2 \mathrm{ng} \cdot \mathrm{L}^{-1}$. In particular, the concentrations of $17 \beta-E 2$ in two ditch water samples were 1.07 and $0.8 \mathrm{ng} \cdot \mathrm{L}^{-1}$, which were close to the lowest observable effect level of $1 \mathrm{ng} \cdot \mathrm{L}^{-1}$ for fish (Routledge et al., 1998). Similar to estrogen assessment, some androgens produce intersex fish when applied during early life stages. For example, Koger et al. (2000) found that medaka larvae developed intersex gonads after only 1 week of exposure to $100 \mu \mathrm{g} \cdot \mathrm{L}^{-1}$ of TS. For PG, a 1 -week exposure of male fathead minnows to a nominal concentration of $300 \mathrm{ng} \cdot \mathrm{L}^{-1} \mathrm{PG}$ was found to reduce sperm motility (Murack et al., 2011). The concentrations of androgen and PG in our study were significantly lower than the corresponding lowest effect concentrations.

Previous studies often reported steroids in surface water affected by municipal wastewater discharge (Chang et al., 2009; Fan et al., 2013). For example, estrogens (total concentrations up to $9.8 \mathrm{ng} \cdot \mathrm{L}^{-1}$ ), androgens (up to $480 \mathrm{ng} \cdot \mathrm{L}^{-1}$ ) and progestogens (up to $50 \mathrm{ng} \cdot \mathrm{L}^{-1}$ ) were detected in urban rivers affected by sewage (Chang et al., 2009). In addition to discharge from a sewage treatment plant, concentrations of steroids in soil, water and sediment also influenced by animal manure application (Table 2). Luo et al. (2013) reported that E1, 17ß-E2, and E3 were found in $18 \%$ of stream water samples, which were also impacted by poultry litter land application, with average concentrations of 1.85 , 4.69 , and $5.04 \mathrm{ng} \cdot \mathrm{L}^{-1}$, respectively. $17 \beta-\mathrm{E} 2$ and E1 were found to transport through runoff stimulated by rainfall after manure application (Finlay-Moore et al., 2000; Lafrance and Caron, 2013; DeLaune and Moore, 2013). Kjaer et al. (2007) observed leaching of estrogens into sub-surface drainage water during heavy rain events, even 3 months after slurry application. In the current study, seven target steroid residues were detected in soils; frequent irrigation was applied to maintain high soil moisture and transport to adjacent ditches by leaching after irrigation might have occurred. Lafrance and Caron (2013) measured high (up to $58 \mathrm{ng} \cdot \mathrm{L}^{-1}$ ) E1 concentrations in stream water near agricultural fields shortly after applications of pig and dairy manure; however, $17 \beta-\mathrm{E} 2$ and E3 were not detected. In the current study, there were low concentrations of $\mathrm{E} 1$ but high concentrations of $17 \beta-\mathrm{E} 2$ in ditch water. The levels of steroid residues in animal manure varied with manure type (Hanselman et al., 2003). A previous study reported that chicken manure, including broiler litter and hen manure, contained less estrogen than pig and cattle manure (Shore and Shemesh, 2003). In particular, E1 was rarely detected in broiler litter (Shore et al., 1993). Therefore, the total amount of E1 entering greenhouse soils with poultry litter application was lower than the amount of $17 \beta-E 2$. Furthermore, the E1 transported to ditches was possibly partly converted into $17 \beta-\mathrm{E} 2$ under anaerobic conditions (Mashtare et al., 2013). Meanwhile, it was noted that high average concentration of $17 \alpha$-E2 was found in ditch sediment. This is possibly because of the biological conversion occurring in the ditch, as exemplified by the conversion of $\mathrm{E} 1$ (originally produced from $17 \beta-E 2$ ) into $17 \alpha-E 2$ under anaerobic conditions (Hutchins et al., 2007). These results might have been obtained because there was a low level of E1 in ditch water adjacent to greenhouse soils. Furthermore, dose-dependent induction of gene expression of vitellogenins (VTG-I), choriogenin $\mathrm{H}(\mathrm{CHG}-\mathrm{H})$ and estrogen receptor a (ERa) mRNA in Japanese medaka (Oryzias latipes) was observed, the benchmark dose (BMD) values of $17 \alpha-\mathrm{E} 2$ for VTG-I, CHG-H and ERa were $44.16 \mathrm{ng} \cdot \mathrm{L}^{-1}, 15.25 \mathrm{ng} \cdot \mathrm{L}^{-1}$ and $66.03 \mathrm{ng} \cdot \mathrm{L}^{-1}$ (Chong et al., 2010). In our study, the average concentration of $17 \alpha-\mathrm{E} 2$ in ditch water was lower than the benchmark dose (BMD) values, which indicated there is no pollution risk to water environment for the present. However, relatively high average concentration of $17 \alpha-\mathrm{E} 2\left(2.94 \mu \mathrm{g} \cdot \mathrm{kg}^{-1}\right)$ was found in sediments. The accumulated $17 \alpha$-E2 in sediments adjacent greenhouses may slowly release to water and pose potential long term ecological risk to fish.

All of the steroids were detected in one or more of the 13 groundwater samples, except for E1 (Fig. 2). The highest detection frequency was obtained for E3 (69.2\%), followed by TS (38.5\%). 17 $\alpha$-E2 and 17 $\beta$-E2 were detected at the same frequency (23.1\%). The detection frequency of $\mathrm{PG}$ was no more than $8 \%$. The average concentration of estrogen (17 $\alpha-\mathrm{E} 2,17 \beta-\mathrm{E} 2$ and $\mathrm{E} 3)$ was $2.02 \mathrm{ng} \cdot \mathrm{L}^{-1}$, with a corresponding

Table 2

Comparison of the mean concentrations of steroids in soil, water and sediment influenced by animal manure application between this study and other research.

\begin{tabular}{|c|c|c|c|c|c|c|c|c|}
\hline \multirow[t]{2}{*}{ Environment media } & \multicolumn{7}{|c|}{ Steroids } & \multirow[t]{2}{*}{ References } \\
\hline & E1 & $17 \beta-E 2$ & $17 \alpha-\mathrm{E} 2$ & E3 & TS & ADD & PG & \\
\hline \multirow[t]{3}{*}{ Soil $\left(\mu \mathrm{g} \cdot \mathrm{kg}^{-1}\right)$} & - & 0.24 & - & - & 0.068 & - & - & Jenkins et al. (2009) \\
\hline & 16 & 5 & 8 & 11 & - & - & - & Dutta et al. (2012) \\
\hline & 2.74 & 1.2 & 0.51 & 0.46 & 0.067 & 1.05 & 4.37 & This study \\
\hline \multirow{2}{*}{ Sediment $\left(\mu \mathrm{g} \cdot \mathrm{kg}^{-1}\right)$} & 0.8 & nd & - & 1.36 & - & - & - & Luo et al. (2013) \\
\hline & 0.28 & 0.27 & 2.94 & 0.33 & 0.05 & 0.09 & 0.28 & This study \\
\hline \multirow[t]{5}{*}{ River water $\left(\mathrm{ng} \cdot \mathrm{L}^{-1}\right)$} & 1.85 & 4.69 & - & 5.04 & - & & & Luo et al. (2013) \\
\hline & 26.9 & nd & - & nd & - & - & - & Lafrance and Caron (2013) \\
\hline & - & - & - & - & 1.5 & & & Shore et al. (2004) \\
\hline & 2.05 & nd & nd & nd & - & - & - & Dutta et al. (2012) \\
\hline & 0.14 & 0.94 & 1.21 & 1.06 & 14.0 & nd & 0.82 & This study \\
\hline Groundwater $\left(\mathrm{ng} \cdot \mathrm{L}^{-1}\right)$ & nd & 0.29 & 0.69 & 1.03 & 0.51 & 0.17 & 0.11 & This study \\
\hline
\end{tabular}


androgen (ADD and TS) concentration of $0.68 \mathrm{ng} \cdot \mathrm{L}^{-1}$. In particular, the concentration of E3 ranged from below the detection limit to $2.38 \mathrm{ng} \cdot \mathrm{L}^{-1}$, with an average concentration of $1.03 \mathrm{ng} \cdot \mathrm{L}^{-1}$, which was higher than the concentrations of the other steroids.

Occurrence of detected steroids varied among soil, ditch and groundwater samples. E1 was found in soil, ditch water and sediment, while the concentration in groundwater was below the detection limit. ADD was detected in soil, groundwater and sediment; however, no residue was found in ditch water. $17 \alpha-E 2,17 \beta-E 2, E 3$, TS and PG were detected in soil, ditch water, sediment and groundwater. As shown in Fig. 2, the concentrations of PG, ADD and E1 were relatively high in soil compared with their concentrations in groundwater. The distribution coefficients $\left(\mathrm{K}_{\mathrm{d}}, \mathrm{L} \cdot \mathrm{kg}^{-1}\right)$ were calculated by the following equation: $K_{d}=S / C$, where $S$ is the concentration of a steroid in soil $\left(\mathrm{mg} \cdot \mathrm{kg}^{-1}\right)$ and $\mathrm{C}$ is the concentration of a steroid in water $\left(\mathrm{mg} \cdot \mathrm{L}^{-1}\right)$. Higher $K_{d}$ values indicated lower transportability of the compounds. The distribution coefficients $\left(K_{d}\right)$ of steroids calculated using their maximum concentrations in soils and waters followed the sequence $\mathrm{PG}>\mathrm{E} 1>\mathrm{ADD}>17 \beta-\mathrm{E} 2>17 \alpha-\mathrm{E} 2>\mathrm{E} 3>\mathrm{TS}$. The same sequence of distribution coefficients $\left(\mathrm{K}_{\mathrm{d}}\right)$ of steroids was calculated using their mean concentrations or median concentrations. The distribution coefficients $\left(\mathrm{K}_{\mathrm{d}}\right)$ of maximum concentrations for PG, ADD and E1 in soil and groundwater were higher than $50 \times 10^{3}$ (Fig. 3). The concentrations of TS and E3 were relatively low in soil but high in groundwater. The distribution coefficients $\left(\mathrm{K}_{\mathrm{d}}\right)$ for TS and E3 in soil and groundwater were lower than $1 \times 10^{3}$ (Fig. 3 ), which suggests that they had higher mobility in greenhouse soil. In particular, TS is more mobile in soil than estrogen and is more likely to be leached from the soil and reach the groundwater (Casey et al., 2003; Lee et al., 2003). Estrogens and androgens have been found in groundwater samples adjacent to operating swine and beef cattle facilities in previous studies (Arnon et al., 2008; Bartelt-Hunt et al., 2011). Groundwater was seriously polluted by sustained release of steroids from animal facilities, with maximum concentrations of E1 up to $390 \mathrm{ng} \cdot \mathrm{L}^{-1}$ in groundwater adjacent to beef cattle facilities (Bartelt-Hunt et al., 2011). However, the polluted domain was within a limited area around the lagoons (Bartelt-Hunt et al., 2011; Arnon et al., 2008). In contrast, groundwater below a large area can be affected by frequent application of manure.

\subsection{Spatial pattern of steroid concentrations in soil and groundwater}

The concentration of PG in the surface soil varied considerably (Fig. 4a). The average PG concentrations in Region 1 were clearly higher than those in Regions 2 and 3. The maximum concentration of PG in Region 1 was up to $109.7 \mu \mathrm{g} \cdot \mathrm{kg}^{-1}$. Soil PG content was relatively low in

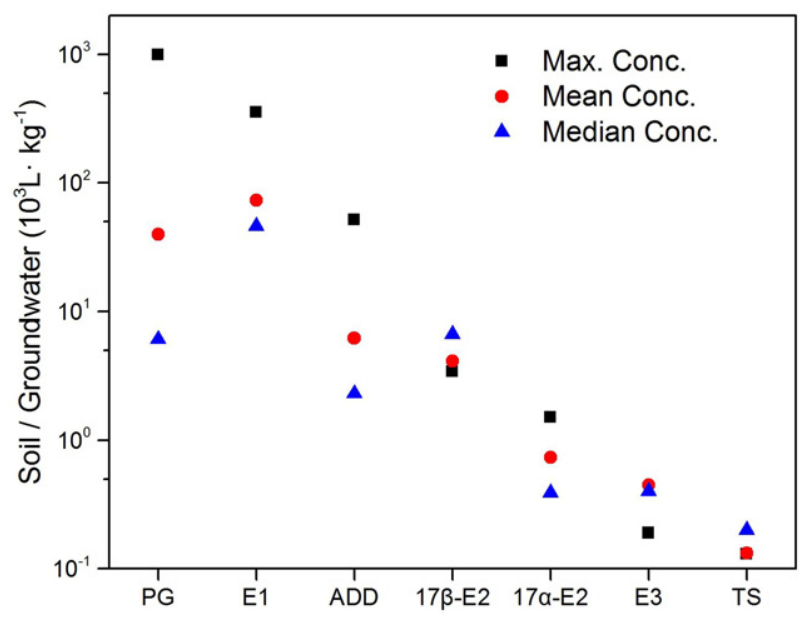

Fig. 3. Maximum, mean and median steroid concentrations in soil compared with ground water for each steroid type.
Region 2. The highest concentration of PG was $1.68 \mu \mathrm{g} \cdot \mathrm{kg}^{-1}$ and it was not detected in several soil samples. In groundwater, PG was detected in only three samples. Therefore, the spatial pattern of PG concentration in groundwater was not consistent with the spatial pattern of PG concentration in soil. The ADD concentrations in soil and groundwater are shown in Fig. 4b. The soil ADD concentrations in Region 1 were higher than those of the other two regions. There were two soil samples with an ADD concentration exceeding $2.00 \mu \mathrm{g} \cdot \mathrm{kg}^{-1}$ in Region 1 . There was only one sample with a soil concentration of ADD higher than $2.00 \mu \mathrm{g} \cdot \mathrm{kg}^{-1}$ in Region 2. Additionally, the maximum concentrations of ADD in Region 3 were lower than $2.00 \mu \mathrm{g} \cdot \mathrm{kg}^{-1}$. ADD was also found in groundwater; however, it was detected in only two groundwater samples. As shown in Fig. 4c, the TS concentrations in Regions 1 and 2 were higher than those in Region 3 . There were two samples containing TS concentrations $>0.08 \mu \mathrm{g} \cdot \mathrm{kg}^{-1}$, while the concentrations of TS in Region 3 were lower than $0.08 \mu \mathrm{g} \cdot \mathrm{kg}^{-1}$. The detection frequency of TS in groundwater was also relatively low. Fig. $4 \mathrm{~d}$ shows that the concentrations of E1 in Region 1 were higher than those of Regions 2 and 3. As shown in Fig. 4e, the samples with E1 concentrations higher than $3.00 \mu \mathrm{g} \cdot \mathrm{kg}^{-1}$ were mostly located in Region 1 . In Region 2, there was only one sample with an E1 concentration higher than $3.00 \mu \mathrm{g} \cdot \mathrm{kg}^{-1}$. The concentrations of E1 in Region 3 were lower than those in Regions 2 and 3. The maximum groundwater concentration of E1 was lower than $2.00 \mu \mathrm{g} \cdot \mathrm{kg}^{-1}$ and the compound was detected in only a small percentage of the total samples. Overall, the residual levels of six steroid hormones showed clear variation in the study area. Although the hormones were detected in groundwater, the concentration levels of compounds in groundwater did not correspond spatially with those in soil.

The fate of manure-borne hormones in soil has been studied extensively. In laboratory experiments, hormones disappeared within timeframes ranging from several hours to several days under simulated agricultural conditions (Colucci et al., 2001; Xuan et al., 2008). Under actual field conditions, our study shows that these steroids can exist for several months in greenhouse soil. In greenhouses, animal manure is applied to soil as a nutrient source for vegetables. The temperature is also maintained higher than that of the outside environment to enhance vegetable growth. Although high temperatures should accelerate the degradation rate of hormones (Xuan et al., 2008), there were several hormone residues detected in greenhouse soils. Therefore, prior to application to greenhouse soils, heavy manure should be treated, i.e., by composting, to reduce the hormone content (Hakk and Sikora, 2011). The detection frequency and the residual concentration of the same hormone type varied between different regions. Furthermore, the concentrations of the same hormones varied within the samples from the same region. In general, the concentrations of hormones were higher in Region 1. Steroids in manure-amended soil can also be transported to the surface and groundwater adjacent to greenhouses. PG, TS, $17 \alpha-$ E2, $17 \beta-E 2$ and E3 were detected in ditch water and groundwater. High soil moisture content will promote the dissolution of hormones and the hormone residues might leach into groundwater through irrigation. Previous studies have shown that hormone concentrations in the first runoff were higher those during later rainfall events (Lafrance and Caron, 2013). Therefore, we suggest avoiding irrigation of greenhouse soil shortly after manure application to reduce the transport of manure-borne hormones to groundwater and surface water. When evaluating the environmental risk of steroids in intensive vegetable cultivation areas, the migration of steroids within different environmental media should be comprehensively analyzed.

\section{Conclusions}

Steroids were detected in soil and adjacent drainage ditch and groundwater samples collected from an intensive vegetable cultivation area The steroid concentrations in soils ranged from below the detection limit to $109.7 \mu \mathrm{g} \cdot \mathrm{kg}^{-1}$. PG, ADD and E1 were found to have relatively high residue concentrations in soil, with concentrations up to 109.7, 

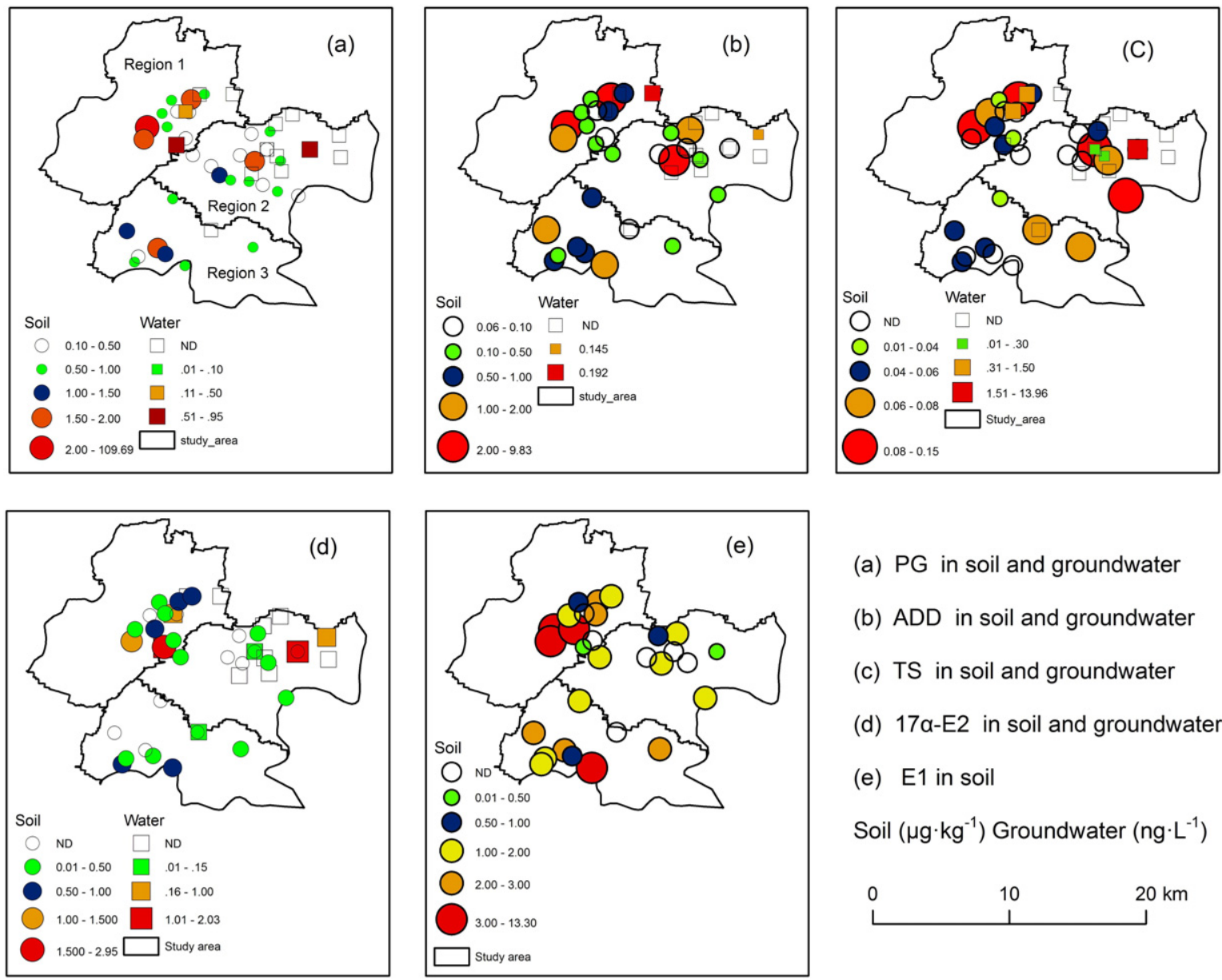

(a) PG in soil and groundwater

(b) ADD in soil and groundwater

(c) TS in soil and groundwater

(d) 17a-E2 in soil and groundwater

(e) E1 in soil

Soil $\left(\mu \mathrm{g} \cdot \mathrm{kg}^{-1}\right)$ Groundwater $\left(\mathrm{ng} \cdot \mathrm{L}^{-1}\right)$

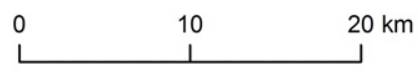

Fig. 4. Spatial patterns of steroid hormone concentration in soil and groundwater

9.83 and $13.30 \mu \mathrm{g} \cdot \mathrm{kg}^{-1}$, respectively. The maximum concentrations of steroids in ditch water and groundwater were up to 14 and $2.38 \mathrm{ng} \cdot \mathrm{L}^{-1}$, respectively. In sediments, the steroid concentrations were up to $2.95 \mu \mathrm{g} \cdot \mathrm{kg}^{-1}$. The pattern of steroid concentrations in soil and groundwater showed clear spatial variation and the heterogeneities were different between steroids. PG, ADD and E1 were found to accumulate relatively easily in soils. However, TS and E3 were easily leached to groundwater. Therefore, pollution risk assessments should focus on TS and E3 in groundwater and PG, ADD and E1 in soil.

\section{Acknowledgments}

This research was funded through the National Natural Science Foundation of China (No. 41201513), National Natural Science Foundation of China (No. 41301229), National Natural Science Foundation of China (No. 21407137), and the central level, Scientific Research Institutes for Basic R\&D special fund business (No. 2013-YSGQ-10).

\section{Appendix A. Supplementary data}

Supplementary data to this article can be found online at http://dx. doi.org/10.1016/j.scitotenv.2015.08.067.

\section{References}

Alvarez, D.A., Shappell, N.W., Billey, L.O., Bermudez, D.S., Wilson, V.S., Kolpin, D.W., et al., 2013. Bioassay of estrogenicity and chemical analyses of estrogens in streams across the United States associated with livestock operations. Water Res. 47, 3347-3363.
Arnon, S., Dahan, O., Elhanany, S., Cohen, K., Pankratov, I., Gross, A., et al., 2008. Transport of testosterone and estrogen from dairy-farm waste lagoons to groundwater. Environ. Sci. Technol. 42, 5521-5526.

Bartelt-Hunt, S., Snow, D.D., Damon-Powell, T., Miesbach, D., 2011. Occurrence of steroid hormones and antibiotics in shallow groundwater impacted by livestock waste control facilities. J. Contam. Hydrol. 123, 94-103.

Bartelt-Hunt, S.L., Snow, D.D., Kranz, W.L., Mader, T.L., Shapiro, C.A., van Donk, S.J., et al. 2012. Effect of growth promotants on the occurrence of endogenous and synthetic steroid hormones on feedlot soils and in runoff from beef cattle feeding operations. Environ. Sci. Technol. 46, 1352-1360.

Bevacqua, C.E., Rice, C.P., Torrents, A., Ramirez, M., 2011. Steroid hormones in biosolids and poultry litter: a comparison of potential environmental inputs. Sci. Total Environ. 409, 2120-2126.

Card, M.L., Schnoor, J.L., Chin, Y.P., 2013. Transformation of natural and synthetic estrogens by maize seedlings. Environ. Sci. Technol. 47, 5101-5108.

Casey, F.X.M., Larsen, G.L., Hakk, H., Simunek, J., 2003. Fate and transport of 17ß-estradiol in soil-water systems. Environ. Sci. Technol. 37, 2400-2409.

Chang, H., Wan, Y., Hu, J.Y., 2009. Determination and source apportionment of five classes of steroid hormones in urban rivers. Environ. Sci. Technol. 43, 7691-7698.

Chong, H., Zhang, Z.B., Wu, S.M., Zhao, Y.B., Hu, J.Y., 2010. In vitro and in vivo estrogenic effects of $17 \alpha$-estradiol in medaka (Oryzias latipes). Chemosphere 80, 608-612.

Colucci, M.S., Bork, H., Topp, E., 2001. Persistence of estrogenic hormones in agricultural soils: I. 17 beta-estradiol and estrone. J. Environ. Qual. 30, 2070-2076.

DeLaune, P.B., Moore Jr., P.A., 2013. 17ß-Estradiol in runoff as affected by various poultry litter application strategies. Sci. Total Environ. 444, 26-31.

Dutta, S.K., Inamdar, S.P., Tso, J., Aga, D.S., 2012. Concentrations of free and conjugated estrogens at different landscape positions in an agricultural watershed receiving poultry litter. Water Air Soil Pollut. 223, 2821-2836.

Fan, Z.L., Hu, J.Y., An, W., Yang, M., 2013. Detection and occurrence of chlorinated byproducts of bisphenol A, nonylphenol, and estrogens in drinking water of China: comparison to the parent compounds. Environ. Sci. Technol. 47, 10841-10850.

Finlay-Moore, O., Hartel, P.G., Cabrera, M.L., 2000. 17ß-estradiol and testosterone in soil and runoff from grasslands amended with broiler litter. J. Environ. Qual. 29, 1604-1611.

Gadd, J.B., Tremblay, L.A., Northcott, G.L., 2010. Steroid estrogens, conjugated estrogens and estrogenic activity in farm dairy shed effluents. Environ. Pollut. 158, 730-736. 
Gall, H.E., Sassman, S.A., Lee, L.S., Jafvert, C.T., 2011. Hormone discharges from a midwest tile-drained agroecosystem receiving animal wastes. Environ. Sci. Technol. 45, 8755-8764.

Hakk, H., Sikora, L., 2011. Dissipation of 17b-estradiol in composted poultry litter. J. Environ. Qual. 40, 121-127.

Hanselman, T.A., Graetz, D.A., Wilkie, A.C., 2003. Manure-borne estrogens as potential environmental contaminants: a review. Environ. Sci. Technol. 37, 5471-5478.

Hu, J.Y., Zhang, H.F., Chang, H., 2005. An improved method for analyzing estrogens in water by liquid chromatography-electrospray mass spectrometry. J. Chromatogr. A $1070,221-224$.

Hu, X., Zhou, Q., Luo, Y., 2010. Occurrence and source analysis of typical veterinary antibiotics in manure, soil, vegetables and groundwater from organic vegetable bases, northern China. Environ. Pollut. 158, 2992-2998.

Hutchins, S.R., White, M.V., Hudson, F.M., Fine, D.D., 2007. Analysis of lagoon samples from different concentrated animal feeding operations for estrogens and estrogen conjugates. Environ. Sci. Technol 41, 738-744.

Jenkins, M.B., Endale, D.M., Schomberg, H.H., Hartel, P.G., Cabrera, M.L., 2009. 17ßEstradiol and testosterone in drainage and runoff from poultry litter applications to tilled and no-till crop land under irrigation. J. Environ. Manag. 90, 2659-2664.

Kjaer, J., Olsen, P., Bach, K., Barlebo, H.C., Ingerslev, F., Hansen, M., et al., 2007. Leaching of estrogenic hormones from manure-treated structured soils. Environ. Sci. Technol. 41, 3911-3917.

Koger, C.S., Teh, S.J., Hinton, D.E., 2000. Determining the sensitive developmental stages of intersex induction inmedaka (Oryzias latipes) exposed to $17 \beta$-estradiol or testosterone. Mar. Environ. Res. 50, 201-206.

Kolodziej, E.P., Sedlak, D.L., 2007. Rangeland grazing as a source of steroid hormones to surface waters. Environ. Sci. Technol. 41, 3514-3520.

Lafrance, P., Caron, E., 2013. Impact of recent manure applications on natural estrogen concentrations in streams near agricultural fields. Environ. Res. 126, 208-210.

Lee, L.S., Strock, T.J., Sarmah, A.K., Rao, P.S.C., 2003. Sorption and dissipation of testosterone, estrogens, and their primary transformation products in soils and sediment. Environ. Sci. Technol. 37, 4098-4105.

Legler, G., Jonas, A., Lahr, J., Vethaak, A.D., Brouwer, A., Murk, A.J., 2002. Biological measurement of estrogenic activity in urine and bile conjugates with the in vitro ERCALUX reporter gene assay. Environ. Chem. 21, 473-479.

Li, X.W., Xie, Y.F., Li, C.L., Zhao, H.N., Zhao, H., Wang, N., et al., 2014. Investigation of residual fluoroquinolones in a soil-vegetable system in an intensive vegetable cultivation area in Northern China. Sci. Total Environ. 468-469, 258-264.

Li, C., Chen, J., Wang, J., Ma, Z., Han, P., Luan, Y., Liu, A., 2015a. Occurrence of antibiotics in soils and manures from greenhouse vegetable production bases of Beijing, China and an associated risk assessment. Sci. Total Environ. 521-522, 101-107.

Li, N., Kang, Y., Pan, W., Zeng, L., Zhang, Q., Luo, J., 2015b. Concentration and transportation of heavy metals in vegetables and risk assessment of human exposure to bioaccessible heavy metals in soil near a waste-incinerator site, South China. Sci. Total Environ. 521-522, 144-151.

Liu, S., Ying, G.G., Zhou, L.J., Zhang, R.Q., Chen, Z.F., Lai, H.J., 2012. Steroids in a typical swine farm and their release into the environment. Water Res. 46, 3754-3768.
Lorenzen, A., Hendel, J.G., Conn, K.L., Bittman, S., Kwabiah, A.B., Lazarovitz, G., et al., 2004 Survey of hormone activities in municipal biosolids and animal manures. Environ. Toxicol. 19, 216-225.

Luo, Q., Adams, P., Lu, J.H., Cabrera, M., Huang, Q.G., 2013. Influence of poultry litter land application on the concentrations of estrogens in water and sediment within a watershed. Environ. Sci. Process. Impacts 15, 1383-1390.

Mashtare, M.L., Lee, L.S., Nies, L.F., Turco, R.F., 2013. Transformation of $17 \alpha$-estradiol, $17 \beta-$ estradiol, and estrone in sediments under nitrate- and sulfate-reducing conditions. Environ. Sci. Technol. 47, 7178-7185.

Mostofa Amin, M.G., Bech, T.B., Forslund, A., Hansen, M., Petersen, S.O., Lægdsmand, M. 2014. Redistribution and persistence of microorganisms and steroid hormones after soil-injection of swine slurry. Sci. Total Environ. 466-467, 1003-1010.

Murack, P.J., Parrish, J., Barry, T.P., 2011. Effects of progesterone on sperm motility in fathead minnow (Pimephales promelas). Aqua. Toxico. 104, 121-125.

Orlando, E.F., Kolok, A.S., Binzcik, G.A., Gates, J.L., Horton, M.K., Lambright, C.S., et al., 2004 Endocrine-disrupting effects of cattle feedlot effluent on an aquatic sentinel species, the fathead minnow. Environ. Health Perspect. 112 (3), 353-358.

Routledge, E.J., Sheahan, D., Desbrow, C., Brighty, G.C., Waldock, M., Sumpter, J.P., 1998 Identification of estrogenic chemicals in STW effluent. 2. In vivo responses in trout and roach. Environ. Sci. Technol. 32, 1559-1565.

Shargil, D., Gerstl, Z., Fine, P., Nitsan, I., Kurtzman, D., 2015. Impact of biosolids and wastewater effluent application to agricultural land on steroidal hormone content in lettuce plants. Sci. Total Environ. 505, 357-366.

Shore, L.S., Shemesh, M., 2003. Naturally produced steroid hormones and their release into the environment. Pure Appl. Chem. 75, 1859-1871.

Shore, L.S., Harel-markowitz, E., Gurevich, M., Shemesh, M., 1993. Factors affecting the concentration of testosterone in poultry litter. Environ. Sci. Health A 28, 1737-1749.

Shore, L.S., Reichmann, O., Shemesh, M., Wenzel, A., Litaor, M.I., 2004. Washout of accumulated testosterone in a watershed. Sci. Total Environ. 332, 193-202.

Slater, C.H., Schreck, C.B., 1993. Testosterone alters the immune response of Chinook salmon, Oncorhynchus tshawytscha. Gen. Comp. Endocrinol. 89, 291-298.

Tso, J., Dutta, S., Inamdar, S., Aga, D.S., 2011. Simultaneous analysis of free and conjugated estrogens, sulfonamides, and tetracyclines in runoff water and soils using solid-phase extraction and liquid chromatography-tandem mass spectrometry. J. Agric. Food Chem. 59, 2213-2222.

Xuan, R., Blassengale, A.A., Wang, Q., 2008. Degradation of estrogenic hormones in a silt loam soil. J. Agric. Food Chem. 56, 9152-9158.

Yost, E.E., Meyer, M.T., Dietze, J.E., Williams, C.M., Worley-Davis, L., Lee, B., et al., 2014 Transport of steroid hormones, phytoestrogens, and estrogenic activity across a swine lagoon/sprayfield system. Environ. Sci. Technol. 48, 11600-11609.

Zhang, H., Shi, J.H., Liu, X.W., Zhan, X.M., Dang, J.H., Bo, T., 2014. Occurrence of free estrogens, conjugated estrogens, and bisphenol $\mathrm{A}$ in fresh livestock excreta and their removal by composting in North China. Environ. Sci. Pollut. Res. 21, 9939-9947. 